\title{
Ludvig Holbergs dansk-norske enevælde
}

I Norge huskedes den lange periode under dansk styre lange som "400 ars-natten", efter hvilken solen stop op ved selvstandigheden $i$ 1814 - men for Holberg var den dansk-norske enevalde derimod "den bedste af alle verdener".

af universitetslektor, ph.d. Sebastian Olden-Jørgensen, Saxo-Instituttet, Københavns Universitet

ret 2014 er lidt af et jubelår.
Første Verdenskrigs udbrud 1914,
Krigen 1864 og så i kanten af horisonten freden i Kiel 1814, som afsluttede godt 400 års dansk-norsk statsfællesskab. Eller er den dansk-norske "fællestid" måske allerede sunket ned under den kollektive erindrings horisont?

Der kan være mange gode grunde til, at fællestiden ikke står så stærkt i den kollektive historiske bevidsthed, men det har ikke noget at gøre med, at der er sket så meget siden. Alle ved, at Christian 4. byggede Rundetårn, var kvindekær og uheldig i krig m.m. Det kan heller ikke skyldes, at fællestiden er specielt belastet. Hvis den var det, ville den sikkert være bedre husket! Svaret er nok snarere todelt: Fællestiden sluttede på en rigtig kedelig måde - set fra dansk side i hvert fald - som en del af rigets yderst triste skæbne som lus mellem to negle under Napoleonskrigene. Danske historikere har også været tilbøjelige til at udpege Frederik 6. (1768-1839, regerende kronprins fra 1784, konge fra 1808) som en uheldig, dvs. inkompetent, statsleder. Sidst, men ikke mindst rummede fællestiden ingen politiske værdier,

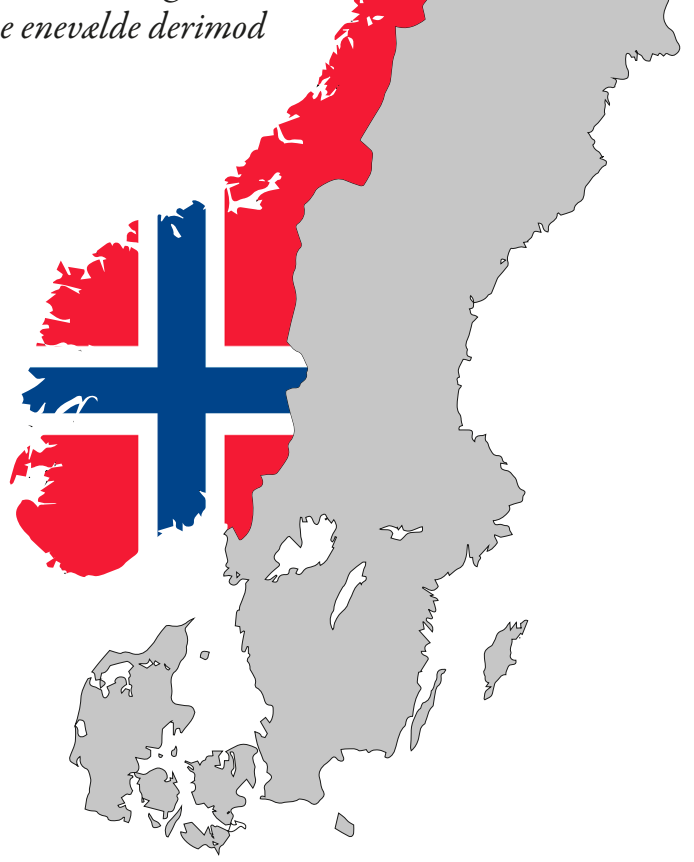

som de følgende generationer har kunnet bruge til noget. Det enevældige dansknorske dobbeltmonarki - og her bør vi heller ikke glemme de tysktalende dele af hertugdømmerne - var ude af trit både med nationalismen, skandinavismen og liberalismen i politik og økonomi.

Heldigvis er vi hverken som historikere eller alment historisk interesserede tvunget til at blive hængende i disse triste fortællinger og den nationale og skandinavistiske fremmedgørelse over for fællestiden. Rent bortset fra at enhver historisk epoke har sin egen værdi, er der også træk i vor egen tid, der på ny reducerer afstanden til Danmark-Norge under enevælden. Nationalstatens svækkelse, EU's 


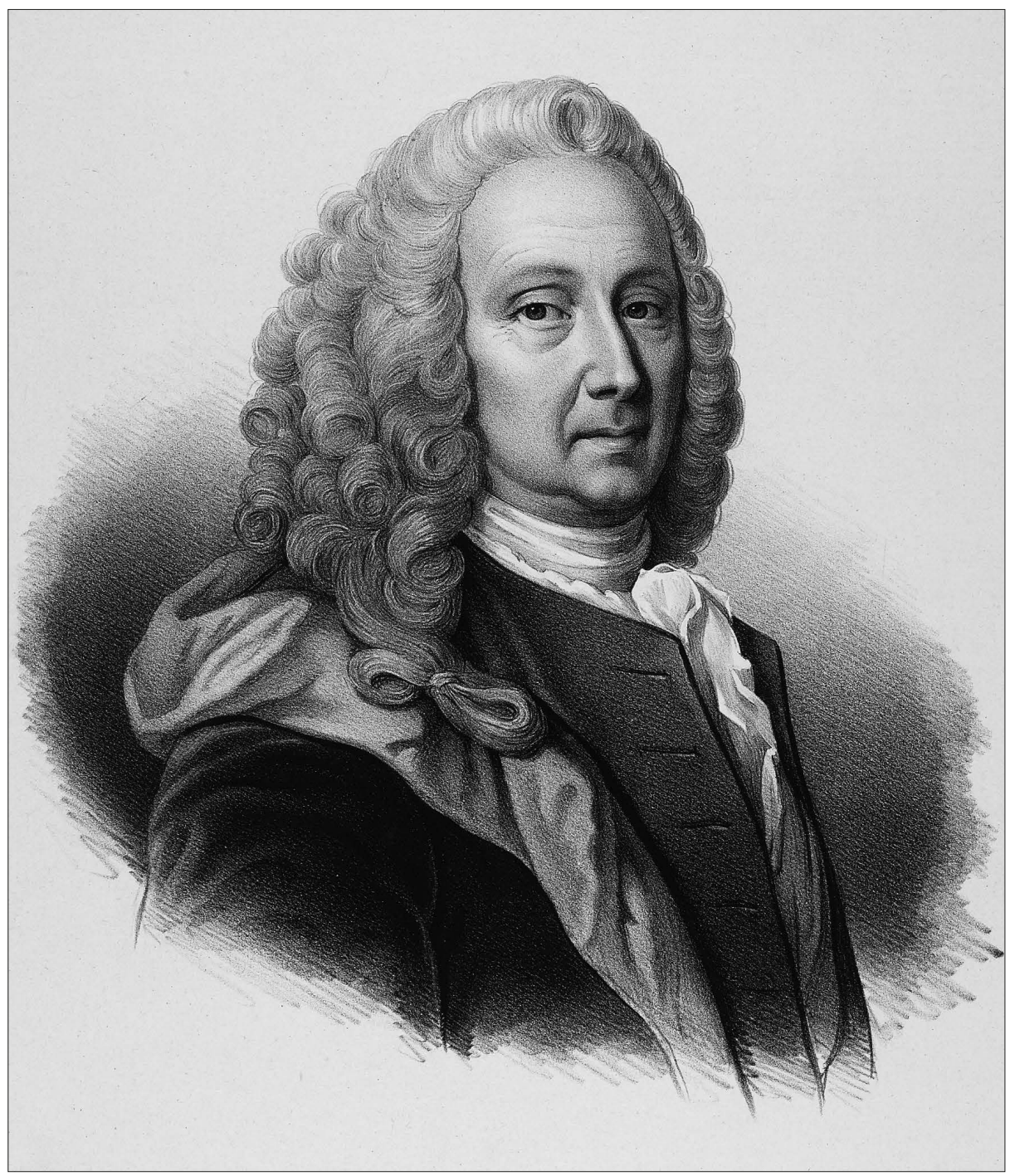

Ludvig Holberg (1684-1754), kultegning efter (kopi af?) Johan Roselius' (1725-1803) beromte original fra ca. 1752, som hang på Sorø Akademi indtil dette brendte i 1813. Ukendt kunster.

fremvækst og et fornyet fokus på oplysningstiden som den vestlige civilisations sande fødselstime har ført os tættere på fællestiden. Det er nok for meget at håbe på, at fællestiden som solen vil stige op på den kollektive historiske bevidstheds middagshøjde, men vi kan da håbe på, at den atter vil komme et respektabelt stykke op over horisonten.

Men hvis fællestiden skal relanceres, må den som så mange andre brands have et ansigt. Og dette ansigt kunne være Lud- 
vig Holbergs. Han udgav i $1729 \sin$ Dannemarks og Norges Beskrivelse, som blev en bestseller, oversat til tysk og udkom i en lidt ændret andenudgave med ny titel tyve år senere (Dannemarks og Norges Geistlige og Verdslige Staat, 1749). Her finder man ikke kun en kortfattet topografisk beskrivelse af Danmark og Norge, men tillige kapitler om folkekarakter, styreform, kongernes historie, økonomiske, sociale, religiøse og retlige forhold. Hans værk er med andre ord et reflekteret produkt af netop den dansk-norske enevælde, da den stod på sin egen middagshøjde i Frederik 4.s sidste år.

Rent personligt illustrerer Holberg også væsentlige aspekter af den dansk-norske enevælde. Han kom til verden i 1684 i Bergen, dobbeltmonarkiets næststørste by, en lille generation inde i enevælden. Hans far var oberstløjtnant, og der var præster og biskopper i slægten. Det er aldrig blevet afklaret, om faderen var dansk eller norsk, og Holberg nævner det ikke selv. Det var ikke interessant, og det er i sig selv interessant for os! Det var derimod interessant for Holberg, at faderen havde deltaget i kampen mod svenskerne i Trondhjem Len under den Anden Karl Gustav-krig 1658-60. Det sørgede han for at få indføjet en lille bemærkning om i Dannemarks og Norges Beskrivelse. Det gav faderen og dermed Holberg en aktie i den dansk-norske enevældes skabelsesberetning.

\section{Holberg og enevældens indførelse}

Den dansk-norske enevælde er nemlig et barn af krigen, de to sammenhængende krige, Første Karl Gustav-krig 1657-58 og Anden Karl Gustav-krig 1658-60 (sammen ofte kaldt Svenskekrigene). Det mente Holberg, og det mener moderne

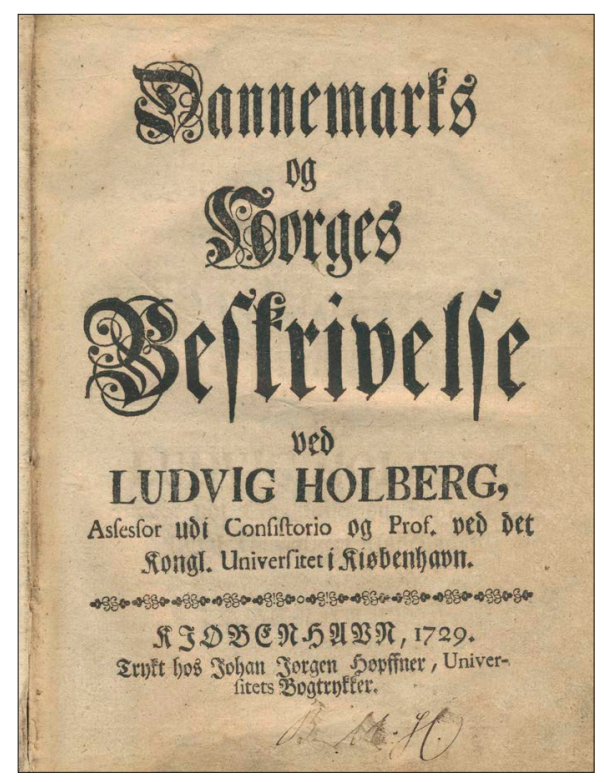

Titelbladet til Dannemarks og Norges Beskrivelse, 1. udgaven fra 1729.

historieforskning også. Det var jo i kølvandet på det fatale nederlag 1658 (togtet over Bælterne, freden i Roskilde) og Københavns belejring under den efterfølgende krig 1658-60, at der blev indkaldt til det store stændermøde i København i efteråret 1660. Stændermødet skulle finde en løsning på de store økonomiske og politiske problemer, krigen havde efterladt. Som bekendt tog mødet midt i oktober 1660 en revolutionær drejning og mundede ud i en statsomvæltning: enevældens indførelse.

Holbergs version af dette forløb, som han skildrer det i Dannemarks og Norges Beskrivelse, er et roligt og rationelt forløb: Efter langvarige, men frugtesløse forhandlinger blev stændermødets deltagere klar over, at den eneste vej ud af dødvandet var at tilbyde kongen enevældig magt og genoprette de gamle danske kongers 
arveret. Initiativet udgik fra borgerstand og gejstlighed, men adelen så hurtigt, hvor nyttigt og nødvendigt det var. Derfor blev Frederik 3. hyldet som arvekonge og kunne den 18. oktober ved en stor ceremoni på slotspladsen modtage stændernes nye troskabsed. Og Holberg konkluderer: "Saaledes blev udi faa dage dette store værk forrettet uden allarm og u-rolighed”.

Dette er imidlertid en sandhed med modifikationer. Sagen er, at enevældens indførelse var et resultat af stærke sociale spændinger, en velorganiseret sammensværgelse og et massivt politisk og militært pres på adel og rigsråd. Det vidste Holberg også godt. Det var nemlig det, der stod i de kilder, man kan se, han har benyttet. Men hvorfor manipulerede han så med den historiske sandhed? Svaret må søges i to retninger. Dels var den version, han gav, i overensstemmelse med styrets ideologi. Officielt, og det vil f.eks. sige i fortalen til Kongeloven (1665), var enevælden netop indført gennem folkets frivillige og velmotiverede magtoverdragelse i efteråret 1660. Det er imidlertid ikke særlig tilfredsstillende at forestille sig, at Holberg skrev, som han gjorde, alene af hensyn til den politiske korrekthed eller af frygt for censuren. Den rigtige historie, altså om klassekamp, sammensværgelse og militært pres på adelen, kunne læses i alment tilgængelig litteratur på dansk, tysk, fransk og engelsk. Han behøvede næppe at tie om det.

Det er derfor rimeligt også at søge årsagen til Holbergs version af enevældens indførelse på et dybere plan, og det vil sige i den overensstemmelse, der var mellem den politisk korrekte version og hans almindelige politiske grundholdning. Holbergs politiske tankegang var nemlig bygget på naturretten i Hugo Grotius' og ikke mindst Samuel Pufendorfs aftapning. Det betød, at staten ikke blot var en forlængelse af familiens naturlige, patriarkalske fællesskab og heller ikke primært en religiøst funderet orden. Staten var derimod en organisationsform, som menneskene engang i fortiden havde valgt for at garantere den fælles sikkerhed. Det var denne sikkerhed og ikke f.eks. frihed eller ejendomsret, som var statens vigtigste formål. Derfor var evnen til at opretholde ydre og indre sikkerhed også den rette målestok, når forskellige politiske systemer skulle sammenlignes og vurderes. Det var en sammenligning, der i Holbergs øjne faldt ud til klar fordel for enevælden. Historiens gang og den almindelige samfundsudvikling bekræftede det: "Man seer at udi disse sidste tider, (nu verden er meere oplysed, end den nogen tid har været) at udi adskillige lande saadan absolut envolds regiering er bleven indførdt". Ja, han gik så langt som til at fastslå: "Frihed er skadelig".

\section{Den bedste af alle verdener}

I det hele taget mente Holberg, at han rent politisk levede i den bedste af alle verdener. I kapitel efter kapitel af Dannemarks og Norges Beskrivelse giver han et historisk rids af udviklingen på et bestemt område: handel, militær, forvaltning etc. Overalt er det grundlæggende plot det samme: Efter en periode i midten af 1600-tallet med indre og ydre svækkelse skabte enevælden efter 1660 styrke, ansvarlighed og ordnede forhold i hele statsapparatet. Om den politiske ledelse havde Holberg kun godt at sige. De oldenborgske konger var en kæde af store og gode herskere, og Frederik 4. (konge 1699-1730) var hans store helt. Det gjaldt både i Dannemarks og Norges 
Beskrivelse og i den mindetale, han holdt på universitetet ved Frederik 4.s død 1730. Her hyldede han kongen som "den sande grundlægger af hæren”, roste hans skattelettelser efter Store Nordiske Krig (1709-1720), fremhævede finansvæsenets gode orden, omsorgen for handelen etc. Det er let at afskrive den slags som genrebestemt hykleri, men omstændighederne taler for, at det faktisk i alt væsentligt var Holbergs ærlige overbevisning. Ingen kunne nemlig dengang være i tvivl om, at den nye konge, Christian 6. (konge 173046), så meget kritisk på sin far. Frederik 4 . havde jo været en vaskeægte bigamist, for endnu mens hans første dronning, Louise, levede, havde han giftet sig til venstre hånd med sin elskerinde, den adelige Anna Sophie Reventlow. Og efter dronning Louises død giftede han sig endnu en gang med Anna Sophie Reventlow, nu til højre hånd, og ophøjede hende til dronning. Alt dette stod i åbenlys modstrid med både den kristne moral, Danske Lov og de sociale konventioner (konger giftede sig ellers kun med fyrstelige). Ja, den fromme Christian 6. var nok tilbøjelig til at se Københavns brand i 1728 som Guds straffedom over kongens skandaløse levned. Man forstår, at overdreven hyldest til Frederik 4. ikke var velset, og Holberg kunne faktisk først lade sin tale trykke efter Christian 6.s død.

Moderne historievidenskab er langt hen ad vejen enig med Holberg i hans vurdering af den enevældige dansk-norske stat som en velorganiseret "magtstat" (militærstat) med en politisk ledelse, der fokuserede snævert på militær råstyrke og de til dette formål nødvendige organisatoriske og fiskale midler. Særlig har historikerne delt Holbergs vurdering af Frederik 4., som han i dedikationen af Dannemarks

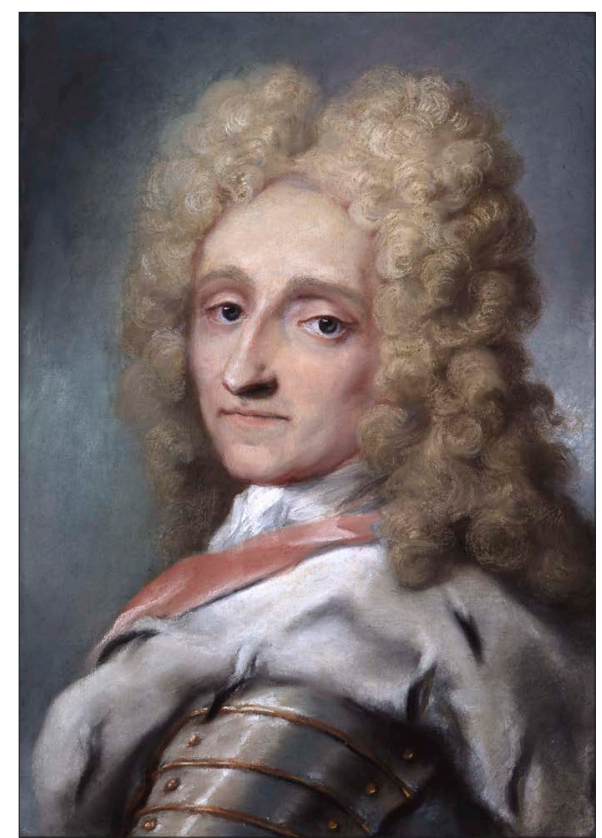

Frederik 4. (1671-1730) blev konge som 18-ärig i 1699. Pastel fra 1709 af Rosalba Giovanna Carriera. Det Nationalhistoriske Museum på Frederiksborg Slot. Foto: Ole Haupt.

og Norges Beskrivelse kalder "den ældste og flittigste Høye Embeds-mand udi landet, og conseqventer alles vores Lære-mester" og i mindetalen roser for at mene, at man som konge bør "dø stående".

\section{Retssikkerhed}

Netop fordi Holberg synes at bekræfte den moderne opmærksomhed på enevældens allermest brutale militære og fiskale sider, er det interessant at se, hvordan Holberg også fremhæver andre aspekter af enevælden. Umiddelbart efter beskrivelsen af enevældens indførelse fortsætter han med at skildre, hvordan Frederik 3. sætter sig for "at stifte en god politie [ว: forvaltning] til den ende, at enhver 
kunde vederfares ret, i hvad stand han var”. Formålet var altså - stadig ifølge Holberg - at garantere undersåtternes, alle undersåtternes, retssikkerhed. Det overrasker derfor heller ikke, at Holberg i mindetalen over Frederik 4. dvæler ved hans respekt for lovene og hans villighed til at acceptere domme, der gik ham imod.

Også på dette punkt har samtidens kritiske iagttagere som ærke-whiggen, den engelske gesandt i København Robert Molesworth (1692) og senere tiders historikere været tilbøjelige til at give Holberg ret. Lovgivningen var særlig efter udstedelsen af Danske Lov 1683 - overskuelig, og retssikkerheden var i almindelighed høj. Alligevel må man også her komme med en korrektion. Holberg har ikke ret $i$, at retssikkerheden fra start af var en af enevældens mærkesager. Tværtimod var enevældens første fire-fem år vidne til en serie skueprocesser (mod Kay Lykke og senere mod Corfitz Ulfeldt), som varslede ilde for alle, der på nogen måde kom i et modsætningsforhold til kongemagten. Man bør heller ikke glemme, at fra 1663-85 sad Corfitz Ulfeldts hustru og Christian 4.s datter, Leonora Christine Ulfeldt, fængslet i Blåtårn uden proces og dom. Man skal også nogle årtier ind i enevælden, før statens kreditorer kunne vide sig sikre mod vilkårlige reduktioner i deres tilgodehavender. Alt i alt må man dog sige, at hvis der ikke var tale om retssikkerhed i det 20. og 21. århundredes forstand, så var der absolut tale om retssikkerhed i det 17. og 18. århundredes forstand.

\section{Social lighed?}

Lighed for loven var altså et anerkendt princip, men hvad med andre former for lighed? Også her har Holberg noget at sige. Han daterede den danske adels privilegerede stilling meget sent, ja i realiteten først til Frederik 1.s tid (konge 1523-33). Først fra dette tidspunkt havde adelens politiske og sociale dominans bragt uorden i samfundet ved at svække kongemagten uhensigtsmæssigt og skærpe modsætningerne mellem stænderne. I dette perspektiv er det indlysende, at enevælden ikke kun måtte føre til en retablering af den kongelige myndighed i dens fulde omfang, men også til en ændring af stændernes indbyrdes forhold i mere ligelig retning. Han berømmede derfor de enevældige konger for at have "ophævet den store u-liighed, som foraarsagede saa stor jalousie mellem undersaatterne, og truede Riget med en fuldkommen undergang".

Det ville dog være en misforståelse at mene, at Holberg - eller enevælden for den sags skyld - gik ind for social lighed i moderne forstand. Adelen havde stadig krav på respekt, men den havde ikke eneret på det! Efter Holbergs mening var enevældens politik rigtig, netop fordi den havde "hanthævet Adelen efter deres stand og værdighed, men derfor ikke udelukket fra vigtige bestillinger [ $\mathrm{s}$ embeder] dem af borgerstand, som have giort sig meriterede". Holberg havde ikke noget imod en elite, men det skulle være en åben elite. Også en anden ting bør man ikke læse hen over: Det afgørende er adgangen til høje embeder i kongens tjeneste, og denne adgang skulle være åben for borgerstanden. Bønder skulle blive, hvor de var.

\section{Centralisering}

Holbergs synspunkt er altså borgerstandens, den borgerstand, der med enevælden fik nye karrierechancer som embedsmænd, og som i bedste fald kunne 
tjene stort på de kombinationer af privat foretagsomhed og statsligt embede, som den tidlige enevælde var så rig på. Det var f.eks. helt almindeligt, at toldembedsmænd lod de opkrævede beløb indgå i deres sideløbende virksomhed som købmænd. Når bare pengene blev indbetalt, og regnskaberne stemte, så var der ingen, der tog anstød af, at ruten mellem borgernes lommer og statens kasser var kroget. Også kompagnihandlen på Grønland, Island, Færøerne og det nordlige Norge og de statslige monopoler rummede store indtjeningsmuligheder.

De nye chancer, enevælden skabte, var imidlertid ikke jævnt fordelt over landet, men i udpræget grad koncentreret i København. Kongelige embedsmænd fandtes godt nok overalt i rigerne, og der blev flere af dem, men både økonomisk og politisk bedrev enevælden en klar centraliseringspolitik. I enevældens første menneskealdre mere end fordoblede København sit indbyggertal, mens landets øvrige købstæder stagnerede og først begyndte at vokse i kølvandet på de gode landbrugskonjunkturer fra midten af 1700-tallet.

Også disse sider af enevælden findes klart afspejlet i Dannemarks og Norges Beskrivelse. Skildringen af centralforvaltningen er yderst detaljeret. Vi oplyses f.eks. om alle 25 forskellige slags kancelliforretninger fra grevelige lensbreve til regulering af skovhugsten, og det anføres, hvad der står på dørene til alle 17 kontorer for renteskriverne (finansembedsmændene). Holberg understreger også, hvordan Frederik 4. har indrettet revisionen (regnskabskontrollen), så den ikke kræver særlig indsigt i det bestemte sagområde, men kan gennemføres af en hvilken som helst regnskabskyndig. På den måde er kontrollen og dermed opsynet med sjusk og fusk blevet gjort både nemmere og mere effektiv.

Også Københavns byforvaltning får en ganske grundig gennemgang, mens forvaltningen i resten af Danmark og Norge skildres ret summarisk. Til slut er der en sektor og en befolkningsgruppe, som Holberg har forbløffende lidt at sige om, i hvert fald set ud fra en moderne synsvinkel, og det er bønderne. I sit kapitel om de forskellige stænder bruges det meste af pladsen på en skildring af adelens historie op til og under enevælden inklusive den nyoprettede greve- og friherrestand. Dernæst følger en kortere gennemgang af borgerskabet og de danske og norske selvejerbønder. Fæstebønderne, der vel udgjorde over $80 \%$ af den danske befolkning, må nøjes med sølle seks linjer. Til gengæld bruger Holberg ret megen plads på en diskussion af vornedskabet (en slags livegenskab-light på Sjælland, LollandFalster og Møn), som blev ophævet i 1702. Denne prioritering er forståelig ud fra værkets overordnede tendens, for ophævelsen var et reelt stykke bondefrigørelse, som Frederik 4., Holbergs helt, gennemførte mod godsejernes vilje, men til fordel både for staten og bønderne. Vornedskabets ophævelse var nemlig tænkt som en kompensation for den for staten billige, men for befolkningen byrdefulde landmilitsordning, bønderne året før var blevet pålagt. Og den frihed til at rejse bort og søge tjeneste uden for godset, som bønderne nu fik eller havde krav på at kunne købe sig til, var netop en fordel for de dygtigste og mest initiativrige bønder, som Holberg ud fra sit meritokratiske livssyn sympatiserede med.

Denne næsten fuldstændige mangel på interesse for fæsteforhold, godsadmi- 


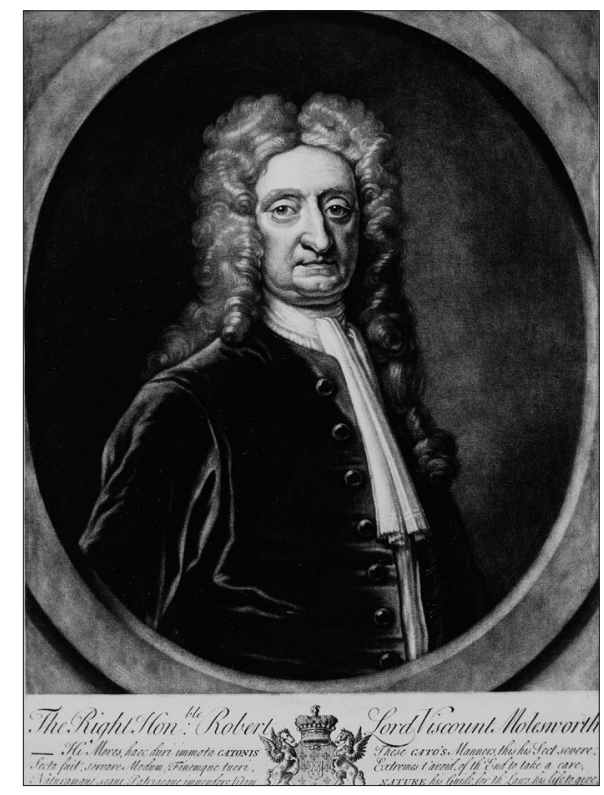

Vel var Robert Molesworth (1656-1725)

"Right Honourable", men han huskes mest for sin skarpe kritik af det danske samfund, som han oplevede det som engelsk gesandt. Det Kongelige Bibliotek. Billedsamlingen.

nistration og landbrug, som kan iagttages i Dannemarks og Norges Beskrivelse afspejler imidlertid en vigtig kendsgerning i den historiske virkelighed i enevældens Danmark: For den danske landbefolknings vedkommende forblev godsejeren et mellemled mellem dem og statsmagten. Det var ham, der administrerede skatteindkrævning, udskrivning af soldater og den lokale retspleje. Først med landboreformerne i slutningen af 1700-tallet begyndte staten for alvor at gribe ind i denne verden af godsejere og fæstebønder, der havde eksisteret i århundreder. Indtil da nøjedes enevælden med at udnytte og kontrollere det traditionelle landbosamfunds institutioner, for det var efter alt at dømme det nemmeste og det mest effektive for styret.
Resultatet var, at enevælden i Danmark på mange måder blev en overbygning på det traditionelle landbosamfund. Holberg selv kom ikke i direkte kontakt med landbosamfundet, før han i 1737 blev kvæstor (økonomiansvarlig) på universitetet og $\mathrm{i}$ 1740 godsejer på Vestsjælland. Da skulle det vise sig, at han sandelig også havde forstand på landøkonomi, men i 1729 faldt landbosamfundet uden for hans enevældigborgerlige horisont.

\section{Dansk og norsk}

Som afrunding på denne lille rundtur i Holbergs enevælde kan vi kaste et blik på hans skildring af dansk og norsk. Gør den samme tendens til en borgerlig-bureaukratisk-københavnsk ensidighed sig også gældende her? Svaret er et betinget nej. Norge og norske forhold fylder ikke lige så meget som Danmark i Dannemarks og Norges Beskrivelse, men de fylder nok så meget, som det var praktisk muligt for Holberg. Hvor han kunne, nævnte han norske forhold, og han bragte f.eks. et længere afsnit om de norske bjergværker, som han havde fået stillet til rådighed af en lokal sagkyndig. Illustrativt er også bogens allerførste kapitel: "Om den danske Nations art og egenskab”. Efter en kort generel introduktion, hvori han bl.a. nævner Robert Molesworths lidet flatterende portræt af Danmark i bogen $A n$ Account of Denmark As It was in the Year 1692 (London 1694), giver han først en længere skildring af "de gamle Danskes og Norskes levemaader”. Det kunne lyde som almindelig kulturhistorie, men handler i realiteten om de gamle nordboeres tapperhed og dødsforagt og munder ud i en sammenligning af dansk og svensk militær styrke. Baggrunden for dette er de store svenske sejre bl.a. på Danmarks bekost- 
ning i 1600-tallet. Heldigvis kan Holberg konstatere, at enevældens indførelse har genskabt den danske tapperhed og militære disciplin.

Derpå følger den berømte skildring af den danske nationalkarakter. Danskeren er i almindelighed lydig mod øvrigheden, ret opfindsom og begærlig efter at lære fremmedsprog, men også magelig, ærekær, overfladisk, slave af moden og særlig i København hengiven til luksus. Frem for alt holder danskeren sig dog på den gyldne middelvej: ikke så flyvsk som en franskmand, men heller ikke så overdrevent eftertænksom som en englænder, ikke så nærig som en hollænder, men stadig mere sparsommelig end en nordmand, ikke så ordrig som en tysker, men heller ikke så tavs som en spanier etc. Ja, "blant alle de folk jeg kiender, incommoderer [ग: besværer] mig de Danskes omgiengelse mindst", siger Holberg.

Danskerne var for Holberg "mine landsmænd", men ved et par lejligheder differentierer han og kalder nordmændene "mine egne landsmænd". Hvad angår forholdet mellem de to folk, må man sige, at Holberg ikke er helt klar i mælet. Først anfører han, at nordmænd lever under et andet klima og derfor adskiller sig meget både i natur og kultur. Samtidig, hævder han, "hindrer den forskiel ikke, at der jo er en fuldkommen foreening og overeensstemmelse imellem begge disse nationer, og have de alletider siden den navnkundige foreening [ว: Kalmarunionen] blev sluttet imellem Dannemark og Norge, været anseede som eet folk." Danske og norske er altså grundforskellige, men alligevel ét folk!

I realiteten er Holbergs skildring af nordmændenes nationalkarakter en mellemting mellem absolut forskellighed og fuldstændig enhed. På en række områder er de ligesom de danske, bare lidt mere: De er endnu mere lydige og loyale over for øvrigheden, endnu taprere i krig, endnu mere opfindsomme og ivrige efter godt købmandskab og endnu bedre til fremmedsprog. På lasternes område er der større selvstændighed, for nordmænd er desværre også tilbøjelige til overlegenhed, stridbarhed og drukkenskab, selv om det på det seneste er blevet bedre, og ingen længere tvinges til at drikke sig sanseløs. Den sidste norske last, Holberg nævner, er stivnakkethed, men det lykkes ham dog at omtolke nordmændenes stædighed og rethaveriskhed til et udtryk for ærlighed. I det hele taget er de ligesom englænderne (og altså helt modsat danskerne) tilbøjelige til at gå til yderlighederne både i positiv og negativ retning! Også finlapperne (samerne) og islændingene får nogle ord med på vejen.

\section{Norsk selvfølelse}

Som man aner, er det ikke uden grund, at senere Holberg-forskere har identificeret en vis "særnorsk" stolthed hos Holberg. I en ganske bestemt passage af Dannemarks og Norges Beskrivelse vokser denne stolthed til noget, der begynder at ligne en politisk selvbevidsthed. Det er i afsnittet om handelen, hvor han anstiller en række ærke-merkantilistiske betragtninger om den dårlige betalingsbalance. Danmark har jo næsten ingen eksportvarer, og danskerne har samtidig stor lyst til fremmede varer, men ingen evne til at importere råvarer og selv forædle dem. Resultatet er ifølge Holberg, at pengene fosser ud af landet, og det ville gå helt galt, hvis ikke den norske eksport af jern, kobber, fisk, træ, beg etc. kompenserede. Ja, Danmark er "som en høy søe, der styrter idelig vand 
ned i det stoore hav, som aldrig kommer tilbage, og Norge som en flod, der falder igien udi samme søe, og derved hindrer, at den saa hastig ikke kand udtørres". Med andre ord: Norske naturressourcer og eksport holder den danske økonomi oppe!

Historieforskningen må langt hen ad vejen give Holberg ret. Gennem dansk kornmonopol i det søndenfjeldske Norge og en løbende overførsel af betydelige told- og skatteindtægter fra Norge til Danmark bidrog Norge substantielt til statsfinanserne og økonomien i det hele taget. Mange norske mænd blev også udskrevet til flåden og vendte aldrig hjem eller fortsatte deres liv som sømænd i den danske eller internationale skibsfart. Med tiden skulle det danne basis for norske krav om en mere norsk-orienteret handelspolitik og selvstændige norske institutioner som f.eks. et universitet. På Holbergs tid lå den slags dog endnu et stykke ude i fremtiden, og man leder forgæves efter krav om norsk selvstændighed hos Holberg. Og man forstår det egentlig godt. Enevælden centraliserede og udsugede både Danmark og Norge, og hovedstaden fik en helt uforholdsmæssig del af kagen. På den anden side blev nordmændene ikke dårligere behandlet end den danske provins.

Om noget så var skattetrykket i Norge (og i hertugdømmerne med for den sags skyld) lidt lavere end i Danmark. I de situationer, hvor den sikkerhedspolitiske situation gjorde det nødvendigt, vendte styret uden tøven strømmen og overførte de nødvendige militære ressourcer til Norge, f.eks. i Store Nordiske Krigs slutfase. Sidst, men ikke mindst gav enevælden Holbergs stand, borgerskabet, talrige karrierechancer. Embedsmandskorpset i Norge var med undtagelse af en vis dansk overvægt i toppen næsten helt norsk, og nordmænd kunne stige helt til tops i kongens tjeneste. Søhelten Peter Wessel Tordenskjold er nok det kendteste eksempel på, hvor langt man kunne nå ved mandsmod og kongegunst, men Holbergs egen skæbne er et andet godt eksempel. Uden synderlige økonomiske eller sociale ressourcer kom han og andre unge mænd fra rigets periferi til København, hvor de fangede kongens opmærksomhed og skabte sig en tilværelse i rigets centrum, i Holbergs tilfælde en akademisk karriere ved Københavns Universitet og senere som godsejer på Vestsjælland, til sidst med titel af baron. Holberg var med god grund enevældens mand.

\section{0}

\section{Litteratur}

Ludvig Holberg: Dannemarks og Norges Beskrivelse. København 1729 (digital udgave findes let på < www.holbergsskrifter.dk >).

Ståle Dyrvik: Truede tvillingriker 16481720. Oslo \& København 1998 (= Danmark-Norge 1380-1814, bind 3.). Ole Feldbæk: Nerhed og adskillelse 17201814. Oslo \& København 1998 (= Danmark-Norge 1380-1814, bind 4.). Sebastian Olden-Jørgensen: "Enevældens indførelse 1660 - en københavnsk revolution", Historiske Meddelelser om Kobenhavn, 2011, s. 19-42.

Sebastian Olden-Jørgensen: "'Saa at jeg har efterlevet en Historieskrivers uden at overtræde en Borgers Pligt' - naturret og historie i Holbergs behandling af enevældens indførelse 1660". I: Eiliv Vinje \& Jørgen Magnus Sejersted (red.): Ludvig Holbergs naturrett. Oslo 2012, s. 118-139. 